\title{
HeS \\ Oxygen Transport Kinetics of Mixed Ionic-Electronic Conductors by Coupling Focused Ion Beam Tomography and Electrochemical Impedance Spectroscopy
}

\author{
Laura Almar, ${ }^{\mathrm{Z}}$ Julian Szász, André Weber, ${ }^{*}$ and Ellen Ivers-Tiffée* \\ Institute for Applied Materials (IAM-WET), Karlsruhe Institute of Technology (KIT), D-76131, Karlsruhe, Germany
}

\begin{abstract}
The oxygen reduction reaction of mixed ionic-electronic conducting (MIEC) cathodes $\mathrm{Ba}_{0.5} \mathrm{Sr}_{0.5} \mathrm{Co}_{0.8} \mathrm{Fe}_{0.2} \mathrm{O}_{3-\delta}(\mathrm{BSCF})$ and $\mathrm{La}_{0.58} \mathrm{Sr}_{0.4} \mathrm{Co}_{0.2} \mathrm{Fe}_{0.8} \mathrm{O}_{3-\delta}$ (LSCF) is investigated by detailed electrochemical impedance spectroscopy and focused ion beam tomography. The oxygen transport parameters of these materials are usually determined for model systems, such as dense bulks or thin films. However in the present study, probable differences regarding the time and thermal history of the samples (e.g. ambient poisoning gases, grain coarsening, secondary phase or surface segregation, etc.) were avoided by the in situ sintering of electrodes with nominal stoichiometry under synthetic air. The microstructural parameters of the electrodes are obtained by 3D FIB-SEM reconstruction tomography and subsequently used in combination with the Adler-Lane-Steele analytical model to calculate a simulated cathode resistance. Large discrepancies are observed compared to the electrochemical impedance measurements. In particular, the electrochemical impedance measurements do not show a Gerischer behavior, as expected for MIEC materials controlled by a coupled surface-exchange and bulk diffusion. Analysis by distribution function of relaxation times (DRT) reveals four individual processes taking place, indicating a surface-exchange controlled behavior with a reaction zone similar to the particle size. Bulk diffusion (D) and surface-exchange (k) coefficients from literature are critically discussed and tentative surface-exchange coefficients (k) for both MIECs are given.

(C) The Author(s) 2017. Published by ECS. This is an open access article distributed under the terms of the Creative Commons Attribution Non-Commercial No Derivatives 4.0 License (CC BY-NC-ND, http://creativecommons.org/licenses/by-nc-nd/4.0/), which permits non-commercial reuse, distribution, and reproduction in any medium, provided the original work is not changed in any way and is properly cited. For permission for commercial reuse, please email: oa@electrochem.org. [DOI: 10.1149/2.0851704jes] All rights reserved.

(cc) BY-NC-ND
\end{abstract}

Manuscript submitted November 22, 2016; revised manuscript received January 27, 2017. Published February 7, 2017.

High-temperature devices such as solid oxide fuel cells (SOFCs) and oxygen transport membranes (OTMs) are promising systems for working towards zero-emissions power generation. The selected materials require high chemical and microstructural stability, as well as high catalytic activity during the oxygen reduction reaction (ORR), under normal operational conditions (i.e. operational temperature and oxygen partial pressure). Particularly interesting are the mixed ionic-electronic conducting (MIEC) materials, based on the $\mathrm{ABO}_{3}$ perovskite structure. Their material properties can be flexibly customized, giving solid solutions with high ionic-electronic conductivity and hence good transport properties. More specifically, $\mathrm{La}_{0.58} \mathrm{Sr}_{0.4} \mathrm{Co}_{0.2} \mathrm{Fe}_{0.8} \mathrm{O}_{3-\delta}$ (LSCF) has become established as the stateof-the-art SOFC cathode, while $\mathrm{Ba}_{0.5} \mathrm{Sr}_{0.5} \mathrm{Co}_{0.8} \mathrm{Fe}_{0.2} \mathrm{O}_{3-\delta}$ (BSCF) has presented outstanding oxygen permeation flux in its cubic phase. ${ }^{1-3}$

The surface-exchange coefficient $(\mathrm{k})$ and the oxygen diffusion coefficient (D) provide key information about the oxygen transport mechanism that dominates the cathodic ORR. Many publications have assessed the D and $\mathrm{k}$ values of MIEC materials, most commonly by; electrical conductivity relaxation (ECR) measurements for dense bulks ${ }^{4-8}$ or thin-films $s^{9,10}\left(\mathrm{k}^{\delta}, \mathrm{D}^{\delta}\right)$ and by oxygen tracer diffusion experiments for thin-films ${ }^{11}$ or powder ${ }^{12}\left(\mathrm{k}^{*}, \mathrm{D}^{*}\right)$.

The oxygen transport parameters are usually determined by ex situ experiments for model systems (i.e. dense ceramics or thin-films). Differences are expected in comparison with in situ measured electrodes, regarding microstructural, ambient or chemical aspects implicitly involved (e.g. surface area, poisoning ambient gases, surface or secondary phase segregation, etc.) which clearly impact the oxygen exchange kinetics. ${ }^{13}$

Adler Lane and Steele (ALS) proposed a continuum analytical model to determine the chemical surface-exchange coefficient $\left(\mathrm{k}^{\delta}\right)$ and the solid state oxygen diffusion coefficient $\left(\mathrm{D}^{\delta}\right)$ values using the impedance of porous MIEC cathodes. ${ }^{14,15}$ In the same direction, Leonide et al. reported a method to render the specific $\mathrm{k}^{\delta}$ and $\mathrm{D}^{\delta}$ values of MIEC cathodes by combining electrochemical impedance spectroscopy with an analysis of the distribution of relaxation times (DRT) and the electrode geometry. ${ }^{16}$ Most recently, Endler-Schuck et al. published the evolution of these parameters as a function of time

*Electrochemical Society Member.

${ }^{\text {z} E-m a i l: ~ l a u r a . a l m a r @ k i t . e d u ~}$ and temperature for LSCF cathodes ${ }^{17}$ Here it should be pointed out that the well-known ALS model can only be applied if the measured impedance shows a Gerischer impedance, which indicates that the surface-exchange and the oxygen bulk diffusion are strongly coupled.

On the other hand the performance of thin-films, nanostructured or high surface-area electrodes are only controlled by their surfaceexchange coefficients. Improving the surface-exchange kinetics of the cathode leads to a cathode solely controlled by the surface-exchange in which the ALS-model could not be applied and a Gerischer impedance is not observed. For instance, Fleig et al. studied the impedance of dense, thin-film cathodes ${ }^{18}$ with surface-exchange controlled kinetics. The measured resistance (a RQ-element) is directly assigned to surface-exchange coefficient $\mathrm{k}^{\delta}$; the $\mathrm{D}^{\delta}$, however, could not be determined. Another prominent example is the nanoscaled LSC cathode presented by Hayd et al., which showed a significantly higher $\mathrm{k}^{\delta}$ value, due to a highly active and dispersed hetero-interphase. ${ }^{19}$

The present work focuses (for the first time) on the oxygen transport kinetics of in situ sintered BSCF and LSCF electrodes. The study was conducted at temperatures from 900 to $600^{\circ} \mathrm{C}$ in synthetic air $\left(79 \% \mathrm{~N}_{2}\right.$ and $\left.21 \% \mathrm{O}_{2}\right)$ and at $\mathrm{T}=700^{\circ} \mathrm{C}$ in mixtures of $\mathrm{N}_{2}$ and $\mathrm{O}_{2}$ from $\mathrm{pO}_{2}=0.02$ to $1 \mathrm{~atm}$ to avoid any microstructural, thermal or environmental degradation. The electrode microstructure parameters were determined by FIB-SEM tomography. They were then fully characterized by impedance spectroscopy (EIS) and the different physical processes involved were identified and quantified by distribution of relaxation times (fitted by complex, nonlinear least squares). After a critical discussion regarding the limits of the ALS-model, the oxygen transport parameters of both MIEC cathodes were assessed.

\section{Experimental}

Symmetrical cells fabrication.-The $\mathrm{Ba}_{0.5} \mathrm{Sr}_{0.5} \mathrm{Co}_{0.8} \mathrm{Fe}_{0.2} \mathrm{O}_{3-\delta}$ (BSCF) powder used in the porous electrodes of the symmetrical cells was synthesized by a solid-state reaction route. Firstly, the precursors were separately ball-milled ( $\varnothing 2-10 \mathrm{~mm} \mathrm{ZrO}_{2}$ balls) in isopropanol to a mean particle size of $\mathrm{d}_{50}=0.5 \mu \mathrm{m}$ (CILAS 1064L) (precursors: $\mathrm{BaCO}_{3}$ (99.5\%, Merck Technipur), $\mathrm{SrCO}_{3}$ (99.7\%, Merck Technipur), $\mathrm{Co}_{3} \mathrm{O}_{4}\left(>98 \%\right.$, ChemPur) and $\mathrm{Fe}_{2} \mathrm{O}_{3}(99.5 \%$, Alfa Aesar). After that, a stoichiometric amount of the precursors was mixed and ball-milled (Ø $20-25 \mathrm{~mm} \mathrm{ZrO}_{2}$ balls) in distilled water for $24 \mathrm{~h}$ to a mean particle 
size of $\mathrm{d}_{50}=2 \mu \mathrm{m}$ with a final calcination step at $900^{\circ} \mathrm{C}$ for 4 hours. A paste was prepared by calendering, composed of $60 \%$ wt solid concentration of the corresponding powder and an organic binder.

The $\mathrm{La}_{0.58} \mathrm{Sr}_{0.4} \mathrm{Co}_{0.2} \mathrm{Fe}_{0.8} \mathrm{O}_{3-\delta}$ (LSCF) screen-printing paste was supplied by the Forschungszentrum Jülich (IEK-1). The powder was synthesized by spray-drying and after calcination at $900^{\circ} \mathrm{C}$ the LSCF powder was ball-milled to a mean particle size of $\mathrm{d}_{50}=0.8 \mu \mathrm{m}$, as described elsewhere. ${ }^{20}$

Each paste was screen-printed onto $\mathrm{Ce}_{0.9} \mathrm{Gd}_{0.1} \mathrm{O}_{2-\delta}$ (GDC) electrolyte pellets (Daiichi Kigenso Kagaku Kogyo Co. Ltd., Japan) with a thickness from 700 to $800 \mu \mathrm{m}$ and dried at $60^{\circ} \mathrm{C}$ for $24 \mathrm{~h}$. Both the fabricated BSCF/GDC/BSCF and LSCF/GDC/LSCF symmetrical cells have active electrode areas of $1 \mathrm{~cm}^{2}$.

Electrochemical and microstructure characterization.-The unsintered samples were placed in a test bench for symmetrical cells between two gold meshes ( $>99.99 \% \mathrm{Au}, 1024$ meshes $\mathrm{cm}^{-2}, 0.06$ mm wires) and pressed with $\mathrm{Al}_{2} \mathrm{O}_{3}$ blocks equipped with gas channels, as described in Refs. 21-23. The BSCF based, symmetrical cells were in-situ sintered with a final temperature step at $900^{\circ} \mathrm{C}$, while the $\mathrm{LSCF}$ required a higher temperature step at $1000^{\circ} \mathrm{C}$ for 3 hours, to achieve a good attachment between electrode and electrolyte. The in situ sintering and all the measurements were done under a controlled atmosphere, with a total flow rate of $500 \mathrm{ml} \cdot \mathrm{min}^{-1}$. Temperature variation measurements from $\mathrm{T}=900$ to $600^{\circ} \mathrm{C}$ were done under synthetic air and at a fixed temperature $\left(\mathrm{T}=700^{\circ} \mathrm{C}\right)$ the oxygen partial pressure was varied from 0.02 to $1 \mathrm{~atm}$.

The electrochemical impedance spectroscopy (EIS) data were recorded with a Solartron 1260 frequency response analyzer in the $0.05-10^{6} \mathrm{~Hz}$ frequency range. The amplitude of the current stimulus was chosen to have a voltage response lower than $30 \mathrm{mV}$. Impedance data analysis was carried out by simultaneously fitting the impedance spectra and the distribution of relaxation time (DRT) curves by complex nonlinear least squares (CNLS) using a self-written MATLAB code based on the Tikhonov-regularisation. ${ }^{24}$

The 3D-microstructure reconstruction of the BSCF cathode was performed by combining focused ion beam (FIB), scanning electron microscopy (SEM) (Zeiss 1540XB, Carl Zeiss NTS GmbH, Oberkochen, Germany) and data processing. More than 600 crosssectional images were collected to obtain a representative volume of $4704 \mu \mathrm{m}^{3}\left(1.74 \cdot 10^{8}\right.$ voxel) from the studied electrode, using a 30 $\mathrm{nm}$ voxel size (volumetric pixel). The SEM tomography data was afterwards segmented by a global threshold and the essential microstructure parameters were calculated.

More details on sample preparation, FIB-SEM microstructure reconstruction procedure, processing of the images and calculation of the parameters can be found in previous studies. ${ }^{25-27}$ The microstructural parameters of the LSCF cathode were obtained by a linear approximation of the FIB-SEM tomography reconstructed microstructure data of cathodes sintered at $960^{\circ} \mathrm{C}$ and $1030^{\circ} \mathrm{C}$ for 3 hours (with the same LSCF paste used in this study). ${ }^{28}$

\section{Results and Discussion}

Microstructure characterization.-SEM cross-section images display the cathode microstructures of the BSCF in Fig. 1a and of the LSCF in Fig. 1b, detailing the cathode/electrolyte interface. Despite the reported thermal mismatch of BSCF on GDC, ${ }^{29}$ good attach- (a)

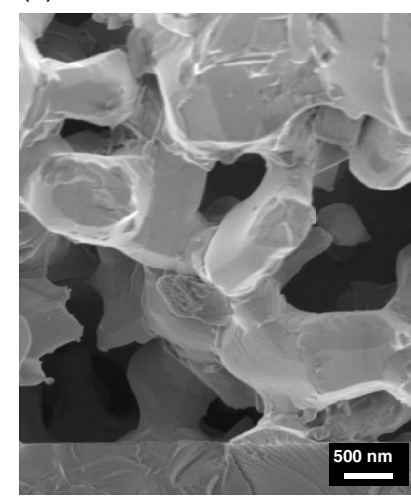

(c)

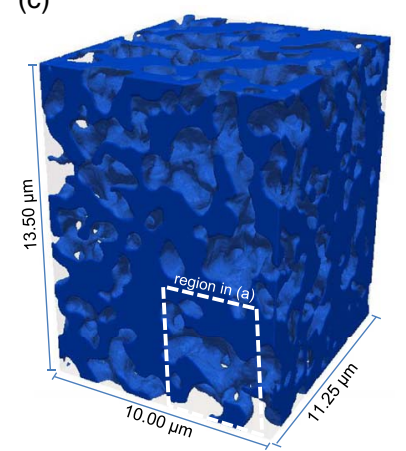

(b)

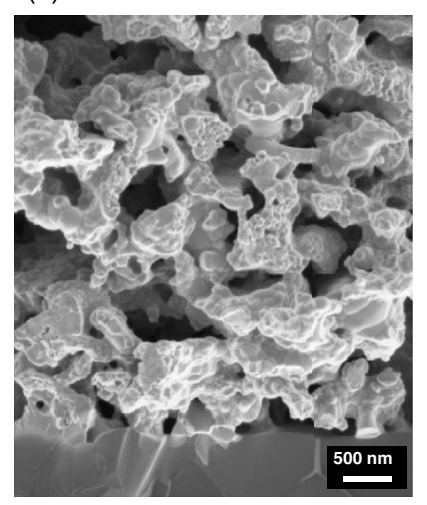

(d)

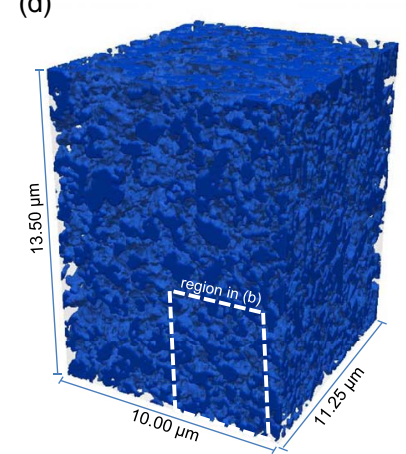

Figure 1. SEM cross-sectional image of the (a) BSCF-CGO interface and (b) LSCF-CGO interface after the electrochemical measurements. 3Dreconstructed volume of (c) BSCF at $900^{\circ} \mathrm{C}$ and (d) LSCF at $1030^{\circ} \mathrm{C}$ obtained by FIB-SEM tomography.

ment was achieved. It probably benefited from the in situ sintering, performed at $\Delta \mathrm{T}=100^{\circ} \mathrm{C}$ temperature steps, from 500 to $900^{\circ} \mathrm{C}$. The BSCF cathodes show a uniform thickness of 30-35 $\mu \mathrm{m}$ and the LSCF cathodes showed 35-40 $\mu \mathrm{m}$. Fig. 1c shows a cut $\left(1519 \mu \mathrm{m}^{3}\right)$ of the representative $3 \mathrm{D}$ reconstructed volume $\left(4704 \mu \mathrm{m}^{3}\right)$ of the BSCF cathode and Fig. 1d shows the comparable 3D reconstructed volume $\left(1519 \mu \mathrm{m}^{3}\right)$ of a LSCF cathode sintered at $1030^{\circ} \mathrm{C}$. As explained the experimental part, the microstructure parameters of the LSCF cathode sintered at $1000^{\circ} \mathrm{C}$ were obtained by a linear interpolation of two LSCF cathodes, sintered at $1030^{\circ} \mathrm{C}$ (Fig. 1d) and $960^{\circ} \mathrm{C}$. The calculated microstructure parameters are summarized in Table I. The porosity fraction $(\varepsilon)$ was obtained by dividing the voxels assigned as pore by the total number of voxels, the surface area $(a)$ was obtained by using the marching cube algorithm and the tortuosity of the solid-phase $\left(\tau_{\text {MIEC }}\right)$ was obtained by solving the transport equation directly from the $3 \mathrm{D}$ data tomography (as described in detail previous studies $^{25-27}$ ).

The porosity fraction $(\varepsilon)$ is slightly above $50 \%$ and similar for both BSCF and LSCF cathodes, although the average particle size of the LSCF $\left(\mathrm{d}_{\mathrm{LSCF}}=282 \mathrm{~nm}\right)$ is smaller than that of the BSCF $\left(\mathrm{d}_{\mathrm{BSCF}}=\right.$ $567 \mathrm{~nm}$ ). As it can also be observed in the SEM cross-section images of Fig. 1, LSCF exhibits a significantly higher surface area $\left(a_{\mathrm{LSCF}}\right.$ $\left.=5.41 \mu^{-1}\right)$, according to the higher sintering activity of BSCF

Table I. Microstructure parameters obtained by the FIB-SEM reconstruction. BSCF cathode in situ sintered at $900^{\circ} \mathrm{C}$ and LSCF cathode sintered at $1000^{\circ} \mathrm{C}$ (obtained by linear interpolation of two LSCF cathodes sintered at 960 and $1030^{\circ} \mathrm{C}$ ).

\begin{tabular}{llll} 
& & $\mathrm{Ba}_{0.5} \mathrm{Sr}_{0.5} \mathrm{Co}_{0.8} \mathrm{Fe}_{0.2} \mathrm{O}_{3-\delta}$ & $\mathrm{La}_{0.58} \mathrm{Sr}_{0.4} \mathrm{Co}_{0.2} \mathrm{Fe}_{0.8} \mathrm{O}_{3-\delta}$ \\
\hline Porosity fraction & $\varepsilon(\%)$ & 51.1 & 53.3 \\
Surface area & $a\left(\mu \mathrm{m}^{-1}\right)$ & 1.69 & 5.41 \\
MIEC tortuosity & $\tau_{\text {MIEC }}$ & 1.77 & 2.62 \\
Particle size MIEC & $\mathrm{d}_{\text {MIEC }}(\mathrm{nm})$ & 567 & 282
\end{tabular}


Table II. Simulated $R_{\text {chem }}$ and $t_{\text {chem }}$ values from 600 to $800^{\circ} \mathrm{C}$ if the ALS-model is applied for BSCF and LSCF electrodes with the microstructure parameters obtained by $3 \mathrm{D}-\mathrm{FIB}$ tomography and $\mathrm{D}^{\delta}$ and $\mathrm{k}^{\delta}$ values from Refs. 5 and 8 , respectively.

\begin{tabular}{|c|c|c|c|c|c|c|}
\hline & $\mathrm{BSCF}$ & & & LSCF & & \\
\hline $\mathrm{T}\left({ }^{\circ} \mathrm{C}\right)$ & 600 & 700 & 800 & 650 & 700 & 800 \\
\hline $\mathrm{pO}_{2}(\mathrm{~atm})$ & 0.21 & 0.21 & 0.21 & 0.21 & 0.21 & 0.21 \\
\hline $\mathrm{D}^{\delta}\left(\mathrm{cm}^{2} / \mathrm{s}\right)$ & $2.21 \cdot 10^{-6}$ & $5.96 \cdot 10^{-6}$ & $9.00 \cdot 10^{-6(*)}$ & $7.18 \cdot 10^{-7}$ & $2.04 \cdot 10^{-6}$ & $7.32 \cdot 10^{-6}$ \\
\hline $\mathrm{k}^{\delta}(\mathrm{cm} / \mathrm{s})$ & $3.50 \cdot 10^{-4}$ & $1.25 \cdot 10^{-3}$ & $5.00 \cdot 10^{-3(*)}$ & $2.28 \cdot 10^{-4}$ & $7.03 \cdot 10^{-4}$ & $1.50 \cdot 10^{-3}$ \\
\hline $1_{\delta}(\mu \mathrm{m})$ & 3.21 & 2.79 & 1.71 & 1.02 & 0.98 & 1.27 \\
\hline $\mathrm{R}_{\text {chem }}\left(\Omega \mathrm{cm}^{2}\right)$ & 0.167 & 0.067 & 0.025 & 0.591 & 0.163 & 0.042 \\
\hline $\mathrm{t}_{\mathrm{chem}}(\mathrm{s})$ & 0.0705 & 0.0196 & 0.0049 & 0.0376 & 0.0122 & 0.0057 \\
\hline
\end{tabular}

${ }^{(*)}$ extrapolated $\mathrm{D}^{\delta}$ and $\mathrm{k}^{\delta}$ value from literature. ${ }^{5}$

$\left(\mathrm{a}_{\mathrm{BSCF}}=1.69 \mu \mathrm{m}^{-1}\right) .^{4,30,31}$ Implicitly the use of a higher sintering temperature to achieve a good LSCF cathode/electrolyte attachment is justified.

Simulation of the cathode impedance.-One can simulate the expected Gerischer impedance by applying the ALS-model taking the microstructure parameters obtained by FIB-SEM tomography and the oxygen transport $\left(\mathrm{k}^{\delta}\right.$ and $\left.\mathrm{D}^{\delta}\right)$ values determined by electrical conductivity relaxation (ECR) measurements for dense bulks..$^{4-8}$ The ALSmodel is an analytical 1D-model developed for semi-infinite thickness, porous, mixed-conducting cathodes with high ionic-electronic conductivity and no gas phase diffusion limitations. It is generally accepted that for thick cathodes the oxygen surface-exchange and the solid-state diffusion processes are coupled and can be described by the following equation, mathematically equivalent to a Gerischer impedance: ${ }^{14}$

$$
Z_{\text {chem }}(\omega)=\frac{R_{\text {chem }}}{\sqrt{1+j \omega t_{\text {chem }}}}
$$

where $R_{\text {chem }}$ is the chemical resistance and $t_{\text {chem }}$ the time constant describing the chemical contributions to the cell impedance and that they are related to the thermodynamic, the oxygen transport properties and the electrode geometry as follows:

$$
\begin{gathered}
R_{\text {chem }}=\frac{R \cdot T}{4 \cdot F^{2}} \cdot \sqrt{\frac{\tau}{(1-\varepsilon) \cdot c_{v} \cdot D_{v} \cdot a \cdot r_{0} \cdot\left(\alpha_{f}+\alpha_{b}\right)}} \\
t_{\text {chem }}=\frac{c_{v} \cdot(1-\varepsilon)}{\gamma_{v} \cdot a \cdot r_{0} \cdot\left(\alpha_{f}+\alpha_{b}\right)}
\end{gathered}
$$

where $\mathrm{R}$ is the gas constant, $\mathrm{T}$ the temperature, $\mathrm{F}$ the Faraday constant, $c_{v}$ the vacancy concentration, $\varepsilon$ the porosity, $a$ the surface area density, $\gamma_{v}$ the thermodynamic factor of vacancies, $r_{0}$ the exchange neutral flux density and where $\alpha_{f}$ and $\alpha_{b}$ are constants of the order of unity.

Simulated values of $\mathrm{R}_{\text {chem }}$ and $\mathrm{t}_{\text {chem }}$ are calculated taking the Equations 2 and $3, r_{0} \cdot\left(\alpha_{f}+\alpha_{b}\right)=\gamma^{-1} \cdot\left(k^{\delta} \cdot c_{m c}\right)$, the microstructure parameters shown in Table I and the $\mathrm{D}^{\delta}$ and $\mathrm{k}^{\delta}$ values of BSCF from Bucher et al. ${ }^{5}$ and of LSCF from Bouwmeester et al. ${ }^{8}$ (further details of the derived equations can be found in Ref. 17). For BSCF, the values of the oxygen lattice sites concentration $\left(\mathrm{c}_{\mathrm{mc}}\right)$ and $\mathrm{O}^{2-}$ concentration were calculated from the constant lattice parameter at each temperature and the thermodynamic factor $(\gamma)$ was taken from literature, ${ }^{5}$ while for LSCF we assumed the same values used by Endler-Schuck et al. ${ }^{17,32,33}$

Simulated $\mathrm{R}_{\text {chem }}, \mathrm{t}_{\mathrm{chem}}$ and $l_{\delta}$ (penetration depth of the cathodic reaction) are shown in Table II at different temperatures from 600 to $800^{\circ} \mathrm{C}$ under synthetic air. Fig. 2 depicts the impedance spectra of the cathodes where the typical Gerischer impedance and the corresponding DRTs can be observed. BSCF shows a lower chemical resistance than LSCF across the temperature range (as expected). The excellent oxygen transport kinetics and large concentration of oxygen vacancies of BSCF led to lower polarization resistance (especially pronounced at lower temperatures) despite its coarser microstructure. The DRT shows a main peak at lower frequencies with a tail end at higher frequencies. The low frequency process which dominates the resistance is associated to the surface-exchange process while the higher frequency tail end includes the oxygen diffusion (bulk) in the cathode, when the oxygen is incorporated over a certain cathode extension length. ${ }^{34}$

Electrochemical characterization.-Figure 3 shows a comparison between the simulated and the measured impedance spectra and the corresponding DRTs of the BSCF/GDC and the LSCF/GDC cells at $\mathrm{T}=700^{\circ} \mathrm{C}$ under synthetic air. Please note that the impedance always shows the contribution of one cathode (half of the symmetrical cell).

A comparison was made between the measured impedance spectra and the simulated impedance spectra for cathodes co-controlled by the surface-exchange and the solid state ionic diffusion. It is unambiguous that the simulated resistances values of 0.067 and 0.163 $\Omega \mathrm{cm}^{2}$ are higher than the measured 0.014 and $0.025 \Omega \mathrm{cm}^{2}$ for BSCF and LSCF cathodes, respectively $\left(\mathrm{T}=700^{\circ} \mathrm{C}\right)$. Interestingly, the DRT curves of the measured cells do not reveal the shape associated to the Gerischer impedance (i.e. a dominating, low frequency process with a higher frequency tail due to the surface-exchange and oxygen diffusion co-controlled regime). Rather, four processes could be identified (Fig. 4 shows a larger magnification of the measured DRTs). The fact that the measured impedance does not show the Gerischer impedance explained in the previous section has the following reasons and subsequent consequences:

1. The measured system is realistic and molecular gas diffusion limitations might occur. Consequentially, an additional process at low frequencies occurs, which can be modeled by an additional RQ-element. ${ }^{14}$

2. The use of MIECs with fast surface-exchange kinetics influence the oxygen reduction reaction in the cathode in such a manner that it might occur in a smaller extension region adjacent to the electrolyte. Adler et al. suggested that if this extension region is very small, the chemical capacitance would be the same order of magnitude as the interfacial capacitance. Resultantly, one could lose the ability to distinguish chemical processes from other processes near the triple phase boundary. ${ }^{15,19}$ As a consequence, the Gerischer (chemical) process is faster, smaller and may overlap with the interface processes (higher frequency processes $f>1000$ $\mathrm{Hz}^{18}$ ). The bulk diffusion shortens the pathway, becoming a nonlimiting parameter. At a certain point the model breaks down and the impedance spectra no longer appears as a Gerischer, but as a semicircle. ${ }^{15}$

3. The frequency of the second peak in the measured impedance spectra is higher $\left(f>100 \mathrm{~Hz}\right.$ at $\left.700^{\circ} \mathrm{C}\right)$ than expected from non-charge transfer related processes $\left(f=1-100 \mathrm{~Hz}\right.$ at $\left.700^{\circ} \mathrm{C}\right)$ $\left(\mathrm{Z}_{\mathrm{chem}}\right) .{ }^{14} \mathrm{~A}$ faster process is a direct indicator of a higher surfaceexchange $\left(\mathrm{k}^{\delta}\right)$, since only $\mathrm{k}^{\delta}$ influences the characteristic frequency and not the oxygen diffusion $\left(\mathrm{D}^{\delta}\right) .^{34}$

All in all, the electrochemical behavior of the measured cells seems unsuitable to be fitted by a Gerischer impedance. Thus, extensive 

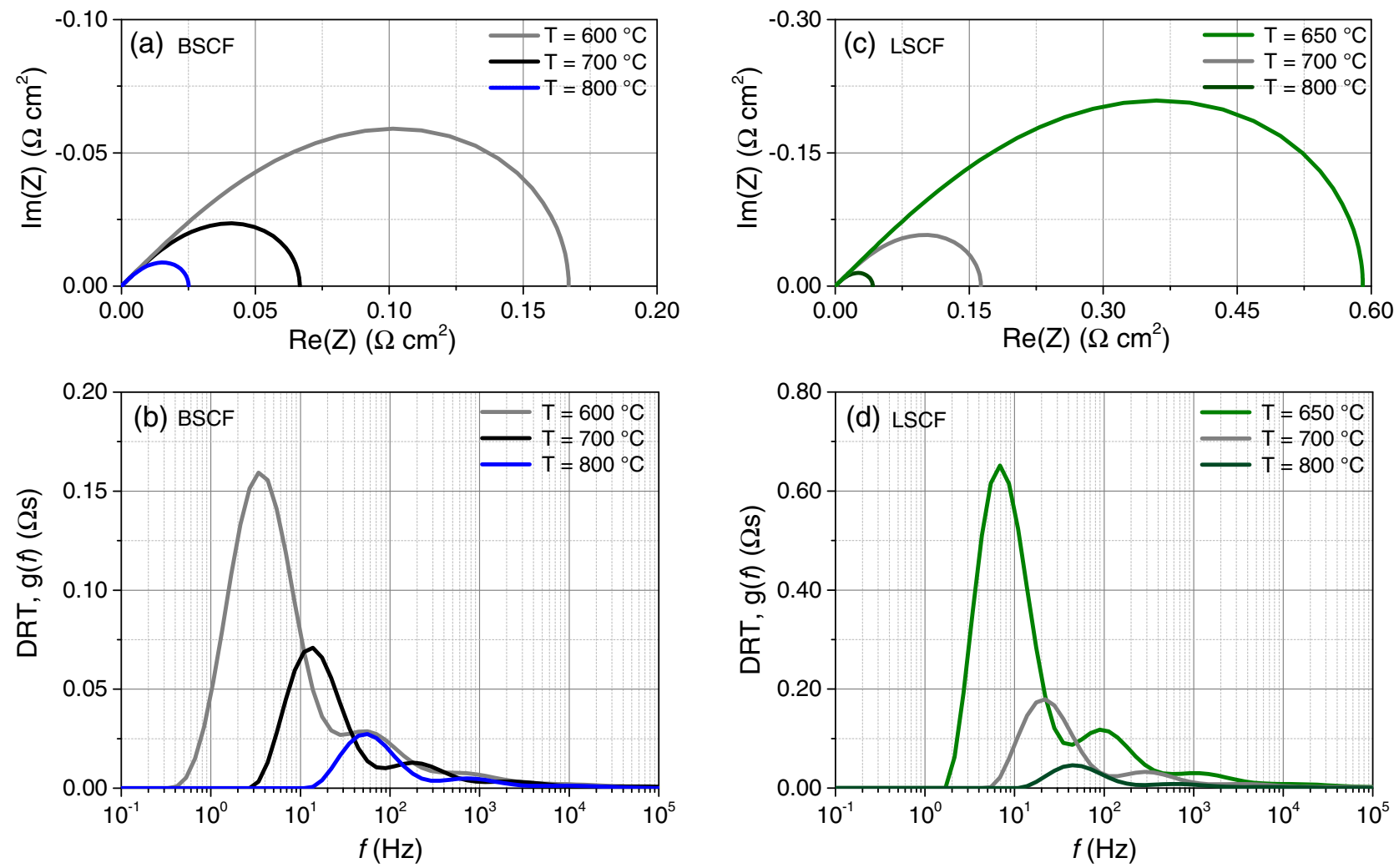

Figure 2. Simulated impedance and corresponding distribution of relaxation time (DRT) curves from $\mathrm{T}=600$ to $800^{\circ} \mathrm{C}$ and $\mathrm{pO}_{2}=0.21$ atm applying the ALS-model (coupled processes of surface-exchange and solid-state diffusion) with the microstructure parameters obtained by 3D FIB-SEM tomography (a, b) for a BSCF-based symmetrical cell and (c, d) for a LSCF-based symmetrical cell (n.b. the impedance shows the contribution of one cathode, half of the symmetrical cell).
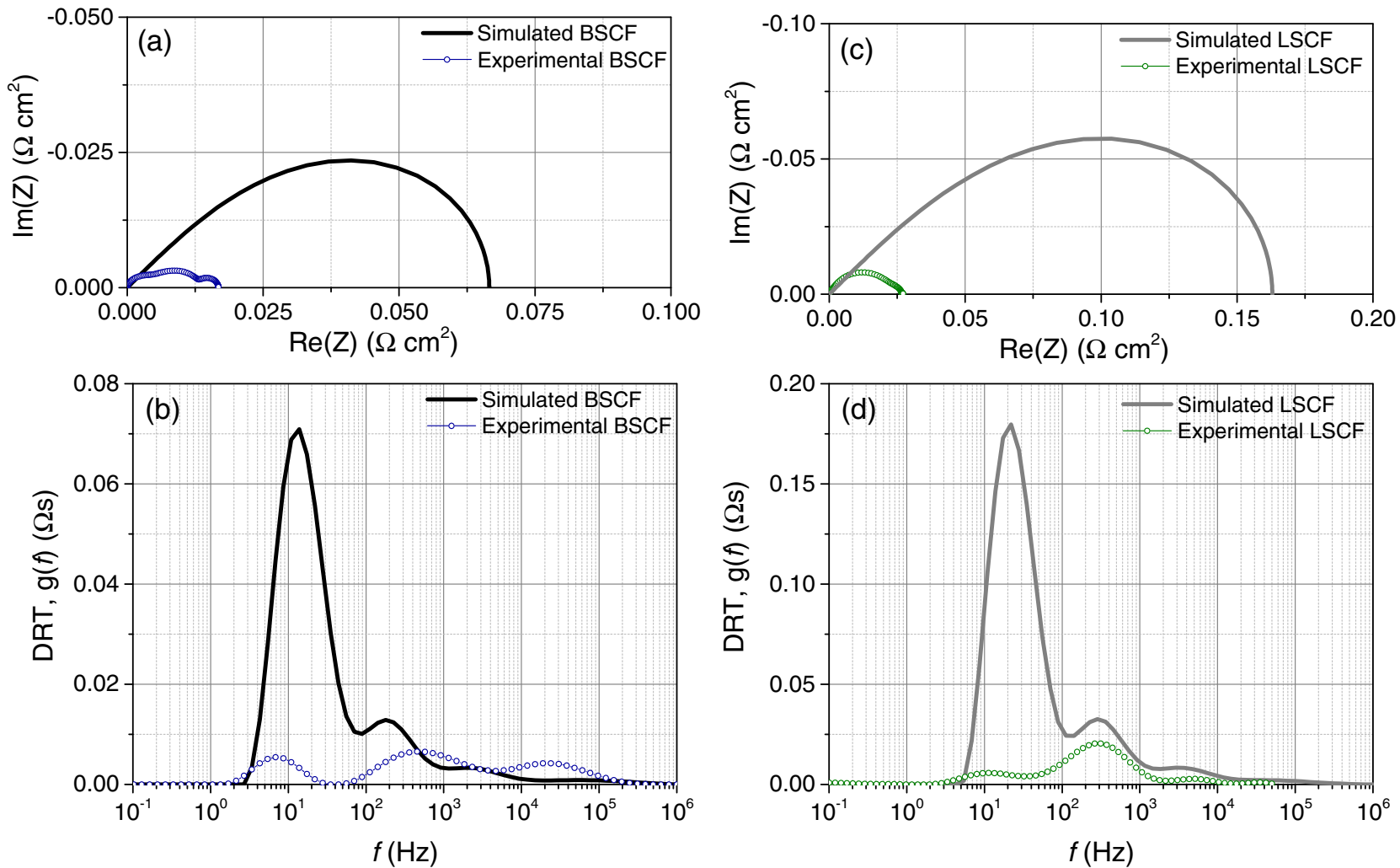

Figure 3. Comparison between the simulated and the measured impedance at $\mathrm{T}=700^{\circ} \mathrm{C}$ and $\mathrm{pO}_{2}=0.21$ atm and the corresponding distribution of relaxation time (DRT) curves $(\mathrm{a}, \mathrm{b})$ for the BSCF/GDC cell and $(\mathrm{c}, \mathrm{d})$ for the LSCF/GDC cell. 

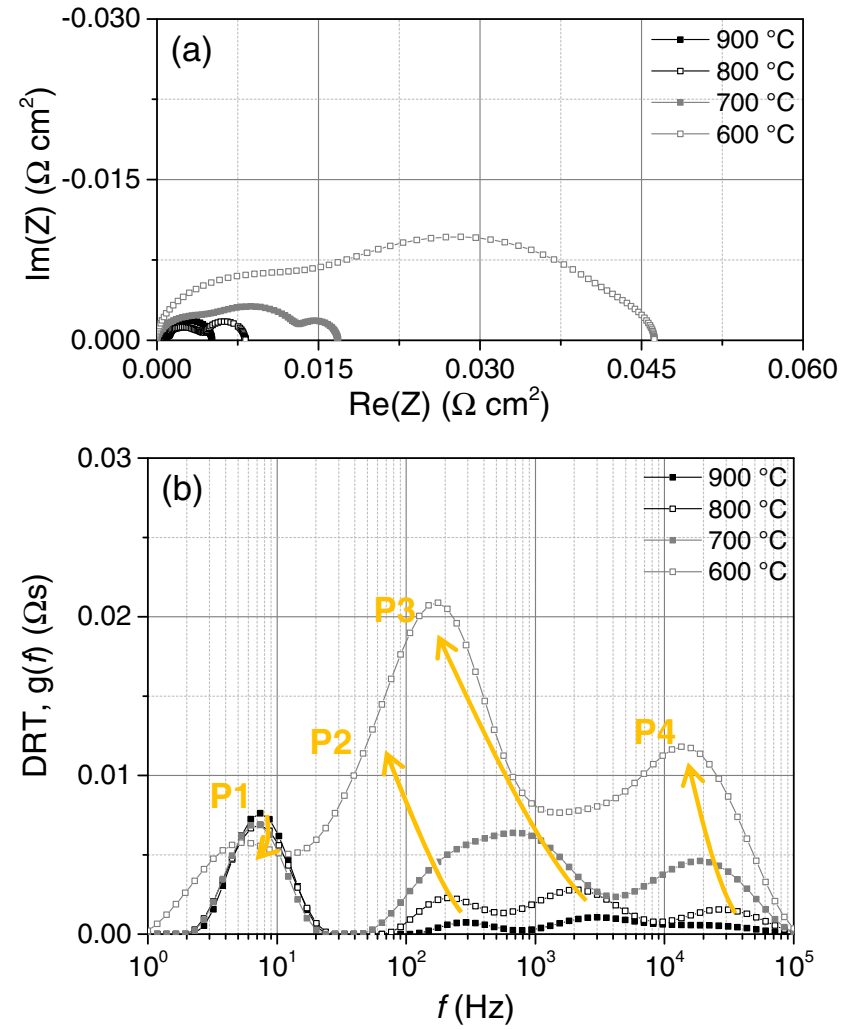

Figure 4. Electrochemical response of a BSCF/GDC/BSCF cell with in situ sintered electrodes at different temperatures from 900 to $600^{\circ} \mathrm{C}$ at a constant oxygen partial pressure $\left(\mathrm{pO}_{2}=0.21 \mathrm{~atm}\right)$, (a) impedance spectra (ohmic losses were subtracted for clarity reasons) and (b) corresponding DRTs.

electrochemical characterization is required to identify all physical processes involved within the MIEC cathode, with respect to the fast oxygen-exchange kinetics. After that, the appropriate equivalent circuit model could be chosen to fit and quantify the different processes. The impedance results of the BSCF/GDC/BSCF cell are shown in Fig. $4 \mathrm{a}$ as a function of temperature from 900 to $600^{\circ} \mathrm{C}$. Figure $4 \mathrm{~b}$ shows the corresponding DRTs where four different processes can be clearly distinguished. A temperature decrease leads to a slight decrease of process $\mathrm{P} 1$, while the magnitudes of processes $\mathrm{P} 2, \mathrm{P} 3$ and $\mathrm{P} 4$ increase, shifting to lower frequencies.

Fig. 5a shows the impedance of the BSCF/GDC/BSCF cell when varying the oxygen partial pressure from 0.02 to $1 \mathrm{~atm}$ at $\mathrm{T}=700^{\circ} \mathrm{C}$. The corresponding DRT curves (Fig. 5b) show that processes P1 (with the strongest $\mathrm{pO}_{2}$ dependency), $\mathrm{P} 2$ and $\mathrm{P} 3$ decrease in magnitude if the oxygen partial pressure increases, shifting to a higher frequency. Process P4 remains almost unaffected.

According to the four processes identified in Figs. 4 and 5, the impedance spectra and the DRT curves were fitted by a complex nonlinear least square (CNLS) to the equivalent circuit shown in Fig. $6 \mathrm{a}$. The area specific resistance (ASR) of the cathode and the single contribution of the processes is presented as a function of the temperature $\left(\mathrm{pO}_{2}=0.21 \mathrm{~atm}\right)$ in Fig. $6 \mathrm{~b}$ and as a function of the $\mathrm{pO}_{2}$ at $\mathrm{T}=700^{\circ} \mathrm{C}$ in Fig. 6c. A plausible physical explanation based on the characteristic time, the tendency and the dependency of each process is given in the following:

- Process 1 (P1) shows low thermal deactivation and has a strong oxygen partial pressure dependency. Since this low frequency process exhibits an oxygen partial pressure dependence of $\mathrm{pO}_{2}{ }^{-0.98}$ close to $\mathrm{n}=-1$, it is associated to molecular oxygen diffusion within the cathode setup, the contacting gold meshes and the porous cathode. ${ }^{35}$ The exponent is in agreement with other reported literature values $\left(\mathrm{pO}_{2}{ }^{-\mathrm{n}}, \mathrm{n}=0.93-1.08\right){ }^{23,36,37}$
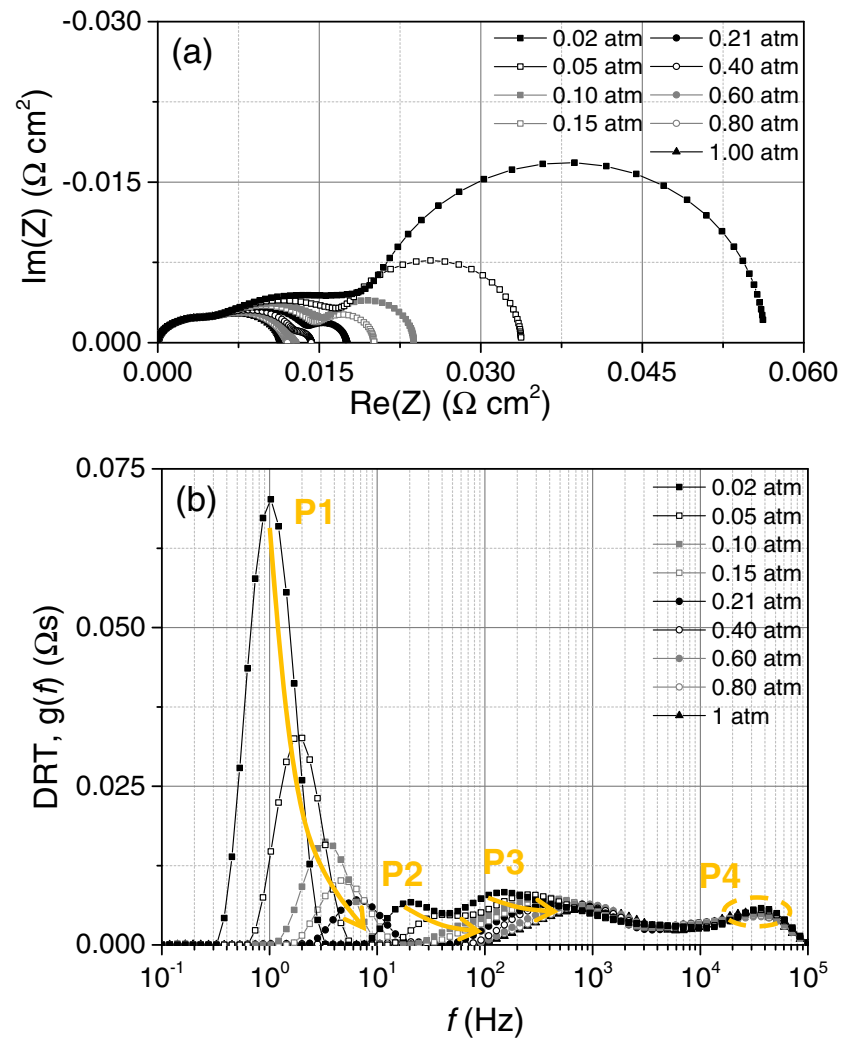

Figure 5. Electrochemical response of a BSCF/GDC/BSCF symmetrical cell with in situ sintered electrodes at different oxygen partial pressures $\mathrm{pO}_{2}=$ $0.02-1 \mathrm{~atm}$ at $\mathrm{T}=700^{\circ} \mathrm{C}$, (a) impedance spectra (ohmic losses were subtracted for clarity reasons) and (b) corresponding DRTs.

- Process 2 (P2) shows thermal activation and is oxygen partial pressure dependent. This mid-frequency is most likely to be caused by the cathodic electrochemical reaction. As explained above, it is faster and smaller than the Gerischer process predicted by the simulated spectra (Fig. 3), which supports the idea of a change in ORR kinetics - from coupled surface-exchange and bulk diffusion to solely surface-exchange controlled. An oxygen partial pressure dependency of $\mathrm{pO}_{2}^{-0.66}$ is in good agreement with the literature values for the surface-exchange reaction $\left(\mathrm{pO}_{2}{ }^{-\mathrm{n}}, \mathrm{n}=0.5-0.6\right){ }^{23,35,38}$

- Process 3 (P3) is thermally activated and shows slight $\mathrm{pO}_{2}$ dependency $\left(\mathrm{pO}_{2}{ }^{-0.09}\right)$. This process with a capacitance of 0.05 to $0.08 \mathrm{~F} / \mathrm{cm}^{2}$ from 600 to $900^{\circ} \mathrm{C}$ has the same order of magnitude as for previously reported interfacial capacitances. It is therefore attributed to oxide transfer losses across the cathode/electrolyte interface (also se ${ }^{15,39}$ )

- Process 4 (P4) is thermally activated but does not change with the oxygen partial pressure. This high frequency process is thus attributed to electronic current losses between the electrode and the current collector (gold mesh), as suggested Adler et al. ${ }^{15}$

The total polarization resistance of the BSCF/GDC/BSCF cell $\left(\mathrm{ASR}_{\text {cat }}\right)$, calculated by the sum of the $\mathrm{P} 2, \mathrm{P} 3$ and $\mathrm{P} 4$ resistance $\left(\mathrm{ASR}_{\mathrm{cat}}=\mathrm{ASR}_{\mathrm{P} 2}+\mathrm{ASR}_{\mathrm{P} 3}+\mathrm{ASR}_{\mathrm{P} 4}\right)$, shows a low value of 47.8 $\mathrm{m} \Omega \cdot \mathrm{cm}^{2}$ at $600^{\circ} \mathrm{C}$ (much lower compared to the simulated values, Table II).

The electrochemical characterization of the LSCF/GDC/LSCF cell shows a similar behavior compared to the BSCF/GDC/BSCF cell (see Supplementary Information). This emphasizes that the physical origin of the identified processes seems to be generally valid for MIEC cathodes with fast oxygen surface-exchange properties. Small differences were observed for process 3 (P3) which can be attributed to a slightly slower transfer of oxygen ions across the LSCF/GDC 

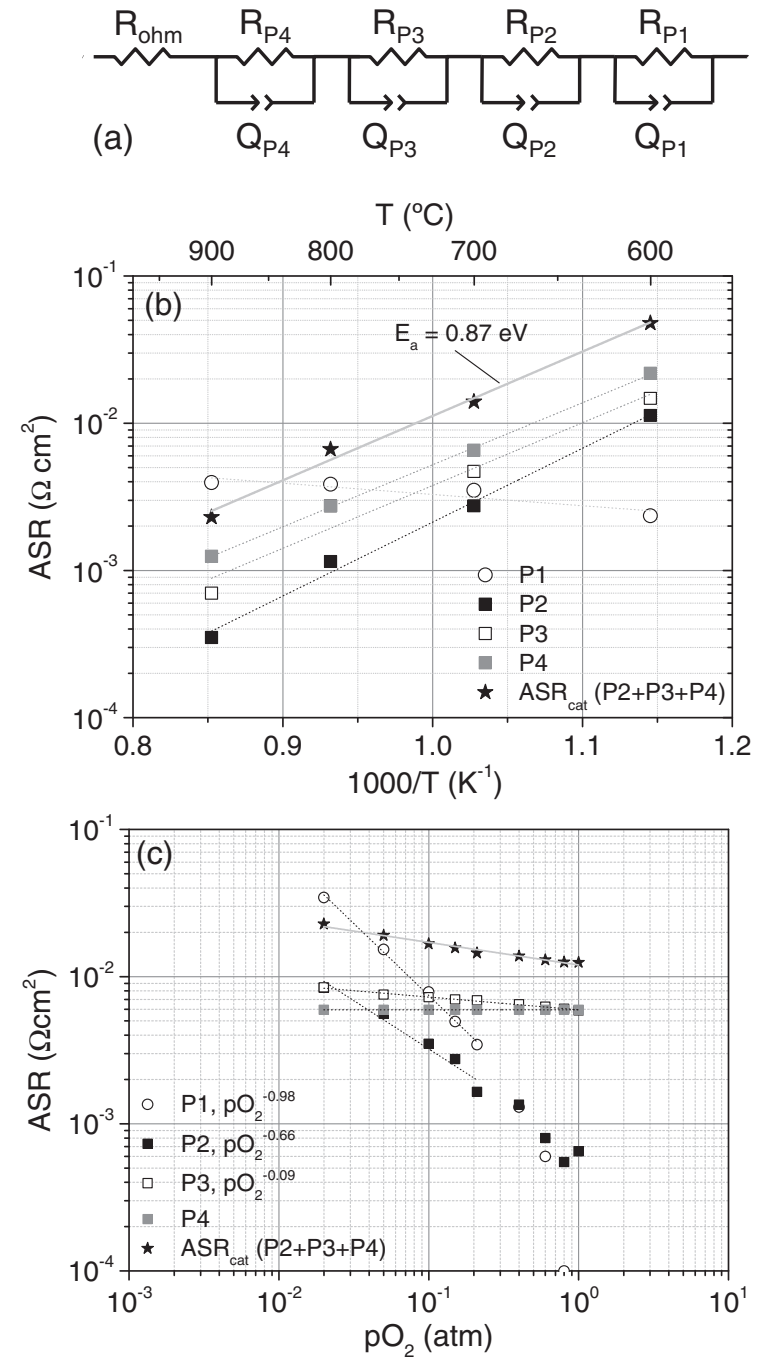

Figure 6. Total area specific resistance and individual process resistance calculated by fitting the impedance and the DRT of a BSCF/GDC cell to the equivalent circuit shown in (a), (b) in a temperature range from 600 to $900^{\circ} \mathrm{C}$ at $\mathrm{pO}_{2}=0.21 \mathrm{~atm}$ and (c) in an oxygen partial pressure range from 0.02 to $1 \mathrm{~atm}$ at $\mathrm{T}=700^{\circ} \mathrm{C}$.

interface. The cause of a smaller process 4 (P4) may be related to: (1) a different contact quality between contact mesh and electrode, or (2) secondary phases at the BSCF/GDC interface, or (3) secondary phases at the grain boundaries of the GDC electrolyte $\left(\mathrm{C}_{\mathrm{GB}} \sim 10^{-8} \mathrm{~F} / \mathrm{cm}^{2}\right){ }^{18}$ Transmission electron microscopy performed at the interface between the BSCF and the electrolyte did not detect any secondary phase at the interface. Only the expected cubic, the hexagonal phase and some cobalt oxide nanoparticles were detected in the porous electrode. A comprehensive analysis of the BSCF/GDC interface is ongoing, but beyond the scope of the present paper. Nevertheless, P4 cannot be attributed to the hexagonal phase formation, since it appears at $\mathrm{T}>$ $840^{\circ} \mathrm{C}$ and $\mathrm{pO}_{2}$ dependency was not observed with changing partial pressure of oxygen. ${ }^{40}$

Determination of $\boldsymbol{k}^{\delta}$.—Once all cathode processes and microstructure parameters have been identified and quantified, an alternative approach is needed to calculate the oxygen kinetic coefficients, without the Gerischer impedance. It should be taken into account that the mathematical Gerischer impedance expression in the ALS-model was derived for the limiting case of semi-infinite (thick) cathodes $\left(l_{\text {cat }}>3 \cdot l_{\delta}\right)$ (Fig. 7a). The penetration depth $\left(l_{\delta}\right.$ defined as the distance that the mixed conductor becomes reduced, i.e. participates in the oxygen-reduction reaction) can be calculated as follows: ${ }^{14}$

$$
l_{\delta}=\sqrt{\frac{c_{v} \cdot D_{v} \cdot(1-\varepsilon)}{a \cdot r_{o} \cdot\left(\alpha_{f}-\alpha_{b}\right)}} \approx \sqrt{\frac{(1-\varepsilon)}{a \cdot \tau} \cdot \frac{D^{\delta}}{k^{\delta}}}
$$

For the simulated impedance spectra of the BSCF based symmetrical cells, a penetration depth of 3.21, 2.79 and $1.71 \mu \mathrm{m}$ at 600,700 and $800^{\circ} \mathrm{C}$ is obtained. For the LSCF cells the $l_{\delta}$ is $1.02,0.98$ and $1.27 \mu \mathrm{m}$ at 650,700 and $800^{\circ} \mathrm{C}$ respectively (Table II).

For thin-film cathodes, however, the penetration depth shifts to a greater length than the cathode thickness $\left(l_{c a t}<l_{\delta}\right)$, therefore the complete cathode volume is reduced and involved in the ORR (Fig. 7b). In this case the oxygen diffusion process becomes negligible; the cathode becomes surface-exchange controlled and the impedance spectra can be fitted as one RQ-element. This expression is normally used for dense thin film cathodes, although J. Hayd et al. derived an expression to take the porosity of a thin-film into account (Fig. 7b-bottom): ${ }^{19}$

$$
Z_{\text {chem }}(\omega)=\frac{R \cdot T}{4 \cdot F^{2}} \cdot \frac{1}{r_{0} \cdot\left(\alpha_{f}+\alpha_{b}\right) \cdot\left(1+j \omega \cdot t_{\text {chem }}\right)} \cdot \frac{1}{a \cdot l_{\text {cat }}}
$$

where $l_{\text {cat }}$ is the cathode thickness and the rest of parameters were defined in Equations 1 and 2. The length of the electrode which participates in the ORR was calculated to be ca. $200 \mathrm{~nm}$ due to the high $\mathrm{k}$-values, while the coarse current-collector layer was electrochemically inert.

As shown in the previous section, the shape of the impedances and DRTs examined in this work indicate a surface-exchange controlled behavior. Thus, a penetration length of a few micrometers and high $\mathrm{k}^{\delta}$ values are expected. The penetration depth is expected to be within the order of magnitude of the particle size $\left(\mathrm{d}_{\mathrm{BSCF}}\right.$ and $\left.\mathrm{d}_{\mathrm{LSCF}}\right)$ and therefore, the other processes localized at the triple phase boundary would become visible. As mentioned by Adler et al., most of the electrode length would be electrochemically inactive and acts only as current collector (Fig. 7c). ${ }^{14}$

In these latter cases the oxygen surface-exchange coefficient $\mathrm{k}^{\delta}$ can be determined by taking $r_{0} \cdot\left(\alpha_{f}+\alpha_{b}\right)=\gamma^{-1} \cdot\left(k^{\delta} \cdot c_{m c}\right)$ and the chemical resistance $\left(\mathrm{R}_{\text {chem }}\right)$ from the fitting results $\left(2 \cdot \mathrm{ASR}_{\mathrm{P} 2}=\right.$ $\mathrm{R}_{\text {chem }}$ ) using the Equation 5:19,41

$$
k^{\delta}=\frac{R \cdot T}{4 \cdot F^{2}} \cdot \frac{\gamma}{R_{\text {chem }} \cdot c_{m c}} \cdot \frac{1}{a \cdot l_{\text {cat }}^{*}}
$$

The Equation 6 has been widely used to calculate the k-value of dense thin-films. ${ }^{18}$ Here the area enlargement introduced by the porous cathode is given by the additional term $\left(a \cdot l_{c a t}^{*}\right)^{-1}$. In this equation $l_{c a t}^{*}$ represents the electrochemical active thickness, i.e. the penetration depth in the ALS-model. As discussed, the ALS-model is valid in the case that a Gerischer impedance dominates the impedance behavior. It is therefore expected that for a surface-exchange controlled regime the $l_{\text {cat }}^{*}$ would be in the range of the penetration depth, calculated from literature, or thinner. Using Equation 6 one can calculate $\mathrm{k}^{\delta}$ values for both BSCF and LSCF electrodes under synthetic air at T $=600$ $900^{\circ} \mathrm{C}$ (assuming plausible values of $l_{c a t}^{*}$, range from the penetration depth obtained with the literature values $\left(l_{\delta}\right)$ (see Table II) down to the particle size (see Table III). Fig. 8 a shows the $\mathrm{k}^{*}$ values for BSCF under synthetic air at $\mathrm{T}=600-900^{\circ} \mathrm{C}$ converted accordingly to $\mathrm{k}^{*}=$ $\gamma^{-1} \cdot \mathrm{k}^{\delta}$, to avoid potential errors in the non-trivial determination of $\gamma$, especially at lower temperatures. ${ }^{17}$ The $\mathrm{k}^{*}$ values obtained by tracer experiments for BSCF thin-films ${ }^{11}$ and by ECR measurements for BSCF bulk samples calculated applying the thermodynamic factor, ${ }^{5}$ are shown as comparison. Meanwhile, Figure $8 \mathrm{~b}$ shows the $\mathrm{k}^{*}$ values of $\mathrm{BSCF}$ at $\mathrm{pO}_{2}$ from 0.02 to $0.21 \mathrm{~atm}$ at $\mathrm{T}=700^{\circ} \mathrm{C}$, assuming the same, plausible, $l_{c a t}^{*}$ values. The concentration of oxygen lattice sites $\left(\mathrm{c}_{\mathrm{mc}}\right)$ was also calculated from XRD measurements, performed at each corresponding condition. ${ }^{42}$

For the same electrochemically active thickness, BSCF presents a higher $\mathrm{k}^{\delta}$ value than LSCF, due to the larger amount of oxygen vacancies, so that even a coarser microstructure shows higher performance. More interestingly, the surface-exchange coefficients calculated for 
(a)
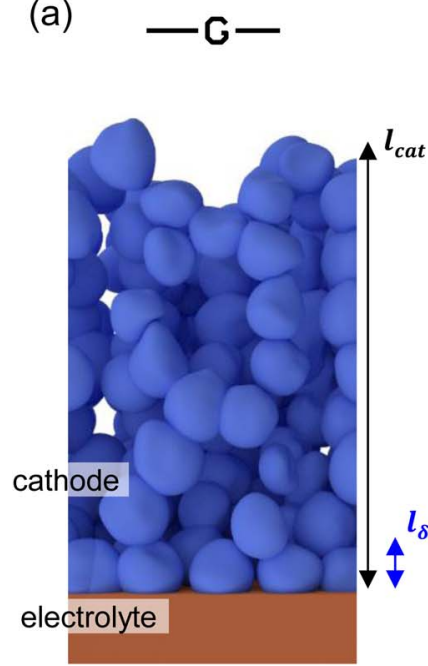

$l_{\text {cat }}>3 \cdot l_{\delta}$ (b)
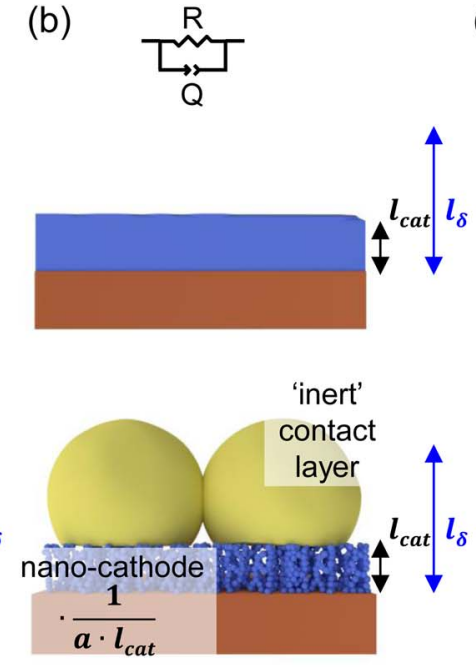

$$
l_{\text {cat }}<\boldsymbol{l}_{\delta}
$$

(c)<smiles>CC1=C(C)[C-]2C[C-]1CO2</smiles>

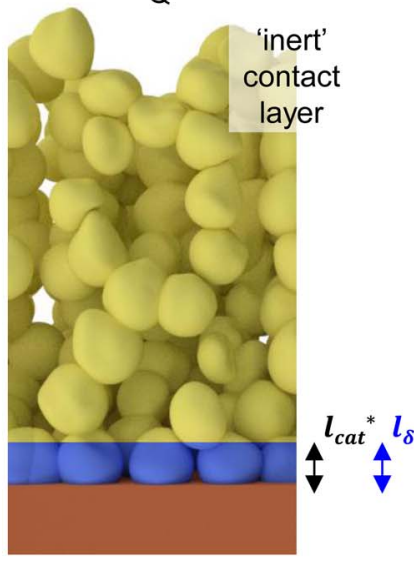

$$
l_{c a t}{ }^{*}=l_{\delta}
$$

Figure 7. Schematic of different MIEC electrode/electrolyte configurations and their impedance response, with respect to the oxygen kinetic controlling mechanism. (a) Thick porous MIEC cathode, co-controlled by the surface-exchange and bulk diffusion, Gerischer impedance response. (b, c) Thin-film or porous MIEC cathode solely controlled by the surface-exchange, RQ-element impedance response, i.e. (b-top) dense thin-film, (b-bottom) porous thin-film and (c) microscaled MIEC cathode with a high surface-exchange coefficient (presented in this work).

\section{Table III. Fitted chemical resistance $\left(\mathbf{R}_{\text {chem }}\right)$ and surface-exchange coefficients $\left(k^{\delta}\right)$ of the BSCF and LSCF porous cathodes. Surface-exchange} controlled at $\mathrm{T}=600-900^{\circ} \mathrm{C}$ under synthetic air.

BSCF

\begin{tabular}{|c|c|c|c|c|c|c|}
\hline $\mathrm{T}\left({ }^{\circ} \mathrm{C}\right)$ & & 600 & 700 & 800 & 900 & 700 \\
\hline $\mathrm{pO}_{2}(\mathrm{~atm})$ & & 0.21 & 0.21 & 0.21 & 0.21 & 0.21 \\
\hline $\mathrm{R}_{\text {chem }}\left(\Omega \cdot \mathrm{cm}^{2}\right)$ & $\left(2 \cdot \mathrm{ASR}_{\mathrm{P} 2}\right)$ & 0.0226 & 0.0055 & 0.0023 & 0.0007 & 0.0063 \\
\hline $\mathrm{D}^{\delta}{ }_{\text {lit. }}\left(\mathrm{cm}^{2} / \mathrm{s}\right)$ & $(5,8)$ & $2.21 \cdot 10^{-6}$ & $5.96 \cdot 10^{-6}$ & $9 \cdot 10^{-6(*)}$ & - & $2.04 \cdot 10^{-6}$ \\
\hline $\mathrm{k}^{\delta}{ }_{\text {lit. }}(\mathrm{cm} / \mathrm{s})$ & $(5,8)$ & $3.50 \cdot 10^{-4}$ & $1.25 \cdot 10^{-3}$ & $5 \cdot 10^{-3(*)}$ & _- & $7.03 \cdot 10^{-4}$ \\
\hline $\mathrm{k}^{\delta}(\mathrm{cm} / \mathrm{s})$ & $\left(1_{\mathrm{cat}}{ }^{*}=1 \mu \mathrm{m}\right)$ & $8.30 \cdot 10^{-3}$ & $4.22 \cdot 10^{-2}$ & $9.35 \cdot 10^{-2}$ & $2.80 \cdot 10^{-1}$ & $1.78 \cdot 10^{-2}$ \\
\hline $\mathrm{k}^{\delta}(\mathrm{cm} / \mathrm{s})$ & $\left(1_{\mathrm{cat}}{ }^{*}=1_{\delta \_ \text {lit. }}\right)$ & $2.59 \cdot 10^{-3}$ & $1.51 \cdot 10^{-2}$ & $5.47 \cdot 10^{-2}$ & - & $1.81 \cdot 10^{-2}$ \\
\hline $\mathrm{k}^{\delta}(\mathrm{cm} / \mathrm{s})$ & $\left(1_{\text {cat }} *=\mathrm{d}_{\text {MIEC }}\right)$ & $1.46 \cdot 10^{-2}$ & $7.45 \cdot 10^{-2}$ & $1.65 \cdot 10^{-1}$ & $4.93 \cdot 10^{-1}$ & $6.31 \cdot 10^{-2}$ \\
\hline
\end{tabular}

LSCF

${ }^{(*)}$ extrapolated $\mathrm{D}^{\delta}$ value from literature. ${ }^{5}$
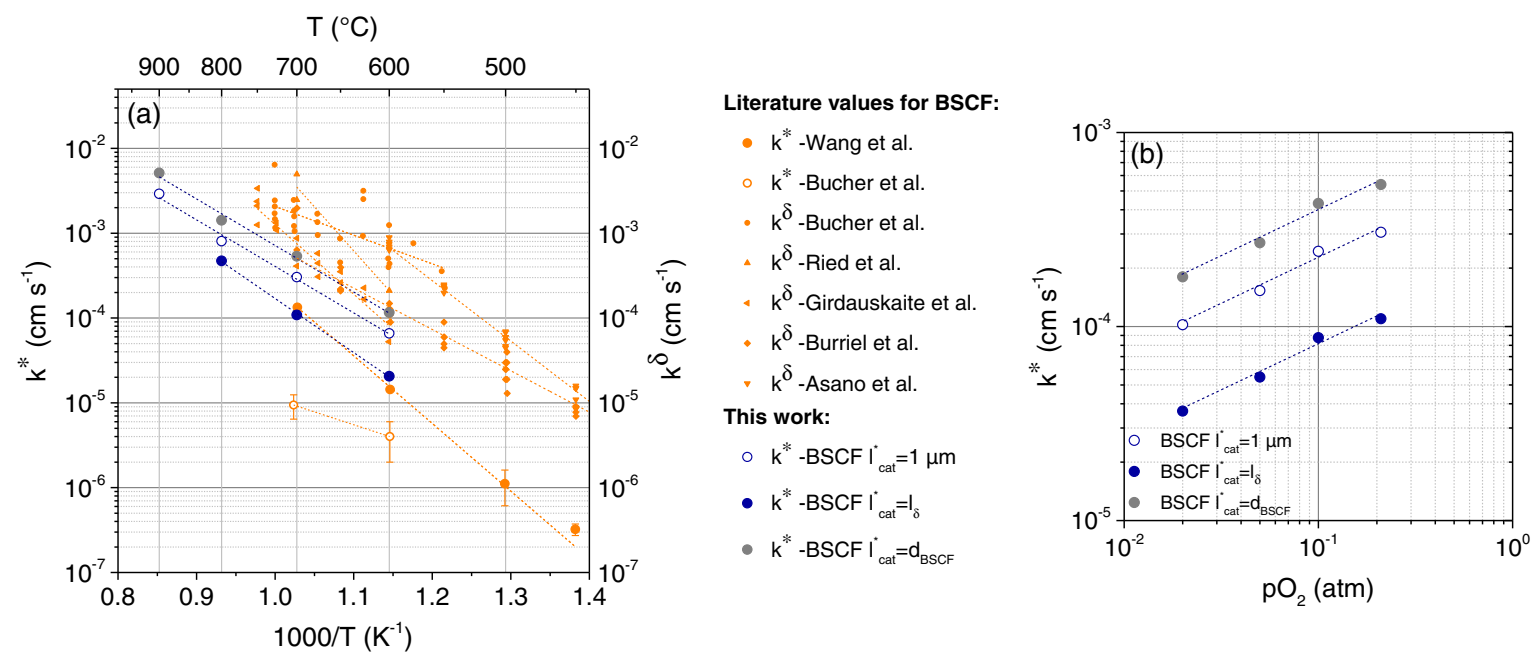

Figure 8. Surface-exchange coefficient $\left(\mathrm{k}^{*}\right)$ of BSCF porous cathodes surface-exchange controlled at (a) $\mathrm{T}=600-900^{\circ} \mathrm{C}$ under synthetic air in comparison with $\mathrm{k}^{*}$ literature values for thin-films from Wang et al. ${ }^{11}$ and for bulk samples from Bucher et al. ${ }^{5}$ (converted according to $\mathrm{k}^{\delta}=\gamma \cdot \mathrm{k}^{*}$ ). The chemical surface-exchange coefficient $\left(\mathrm{k}^{\delta}\right)$ for thin-films from Burriel et al. ${ }^{10}$ and Asano et al. ${ }^{9}$ and for bulk samples from Bucher et al., ${ }^{5}$ Ried et al. ${ }^{4}$ and Girdauskaite et al. ${ }^{6}$ are also given as comparison. (b) Surface-exchange coefficient $\left(\mathrm{k}^{*}\right)$ of BSCF porous cathodes at $\mathrm{pO}_{2}=0.02-0.21$ atm at $\mathrm{T}=700^{\circ} \mathrm{C}$. 
the plausible effective cathode thicknesses are in general higher than the literature values. ${ }^{5,8}$ The $\mathrm{k}^{*}$ values determined for BSCF thin-films by tracer experiments show the smallest difference to the values calculated in this work. ${ }^{11}$ In any case, the $\mathrm{k}$ values plotted in Fig. 8a reveal clearly a scatter which is independent of the technique used i.e. ECR measurement $\left(\mathrm{k}^{\delta}\right)$ or oxygen tracer diffusion experiments $\left(\mathrm{k}^{*}\right)$ and of the nature of the ceramic sample itself i.e. thin-film or dense bulk. In fact, divergence is observed in k-values determined with the same sample and experiment. ${ }^{4-6,9,10}$

The most feasible explanation of the difference in values is therefore a differing nature of the materials themselves along the time or thermal history of the samples which can surmise degradation of the active surface of the materials. Recently, Druce et al. studied the chemistry of the outer atomic layers of a series of perovskite ceramic materials by Low-Energy Ion Scattering (LEIS) and were able to prove that the outer atomic layers show segregation of the A-site cations. ${ }^{13,43}$ The very high k-values obtained at the confined cathode/electrolyte interface are prone to change, depending on different fabrication processes or operation conditions. Many recent studies have focused on:

1: the LSCF surface segregation, ${ }^{13,43}$

2: secondary phase formation at the interface cathode/electrolyte, ${ }^{44}$

3: degradation due to gas contaminants $\left(\mathrm{CO}_{2}, \mathrm{SO}_{2}, \mathrm{Cr}, \mathrm{Si}\right.$, etc. $),{ }^{45-47}$ which affects the $\mathrm{k}$-value and the controlling kinetic mechanism.

This approach was investigated by Endler-Schuck et al., who extracted the evolution of $\mathrm{k}^{\delta}$ and $\mathrm{D}^{\delta}$ as a function of temperature for porous LSCF cathodes in full cells for several hundred hours of operation. A comparison between the $\mathrm{k}^{\delta}$ and $\mathrm{D}^{\delta}$ obtained in their study to the literature values gives the same order of magnitude after a 200 hour degradation test at $750{ }^{\circ} \mathrm{C} .{ }^{17}$ In this case, the impedances of the LSCF cathodes were fitted with a Gerischer impedance, which was by far the smallest contribution to the overall polarization resistance of the investigated anode supported cells. It is worth noting that this work investigated in situ sintered and non-degraded electrodes, operated in synthetic $\left(79 \% \mathrm{~N}_{2}\right.$ and $\left.21 \% \mathrm{O}_{2}\right)$ air and that the symmetrical cells only display cathode contributions.

Further interesting studies are currently carried out. One approach is to perform experiments in $\mathrm{CO}_{2}$ and $\mathrm{SO}_{2}$ containing atmospheres to observe the change to a regime co-controlled by the surface and the bulk diffusion (Gerischer impedance). Another approach could be sintering at higher temperatures, which might lead to an accelerated surface segregation and (one would expect) k-values closer to the dense bulk samples found in literature. Moreover, analysis by analytical (scanning) transmission electron microscopy ((S)TEM) combined with energy dispersive X-ray spectroscopy (EDXS) to study the chemical composition of the electrodes and of the electrode-electrolyte interface are in process.

As a whole by this study, the identification and quantification of the different processes involved during the oxygen reduction reaction of non-degraded porous MIEC cathodes were obtained. Moreover, their actual microstructural parameters were calculated and tentative $\mathrm{k}$-values of the solely oxygen surface-exchange cathodes are given, depending on plausible effective cathode thicknesses.

\section{Conclusions}

The exceptionally fast oxygen surface-exchange properties of BSCF and LSCF were tested. The MIEC cathode materials were in situ sintered and electrochemically characterized as porous electrodes in symmetrical cells. The microstructure parameters were determined from FIB-SEM tomography and data processing. Analysis of the DRTs curves allows the identification of four different physical processes: gas diffusion losses, chemical losses (i.e. oxygen surfaceexchange), interfacial ionic and electronic losses. The contribution of the different processes was quantified by CNLS fitting of the impedance spectra and the DRT curves to a meaningful electrical equivalent circuit. Specifically, a very low cathode specific resistance of $47.8 \mathrm{~m} \Omega \mathrm{cm}^{2}$ at $600^{\circ} \mathrm{C}$ and 0.21 atm was achieved for BSCF.

According to the impedance analysis, the oxygen transport kinetics of the in situ sintered cathodes is solely oxygen surface-exchange controlled. The penetration depth decreases to the size of the cathode particle (approximately) determined as $567 \mathrm{~nm}$ for BSCF and as $282 \mathrm{~nm}$ for LSCF by FIB-SEM tomography. Therefore, a Gerischer impedance is not observed and the ALS-model cannot be used to determine $\mathrm{k}^{\delta}$ and $\mathrm{D}^{\delta}$ values. An alternative approach to determine the oxygen surface-exchange coefficient is presented and tentative values are calculated depending on the plausible effective cathode thicknesses. Overall the in situ sintered MIEC cathodes examined in this study present a higher k-value (by an average factor of 32) than previously reported in literature, most likely due to the different degradation mechanisms that have been always implicit in the history of the conventional model samples, i.e. dense and thin-films.

\section{Acknowledgments}

The authors sincerely thank J. Costard and Dr. J. Joos for their help with the FIB-SEM tomography reconstruction. Sincere thanks are given to Dr. N. H. Menzler and W. Herzhof from the Forschungszentrum Jülich for the generous supply of LSCF paste and J. Packham for proofreading the manuscript. The financial support of the Deutsche Forschungsgemeinschaft (DFG) throughout projects IV 14/21-1 and IV $14 / 16-2$ is highly acknowledged.

\section{References}

1. Z. Shao, W. Yang, Y. Cong, H. Dong, J. Tong, and G. Xiong, J. Memb. Sci., 172, 177 (2000).

2. J. F. Vente, W. G. Haije, and Z. S. Rak, J. Memb. Sci., 276, 178 (2006).

3. Z. Chen, R. Ran, Z. Shao, H. Yu, J. C. D. da Costa, and S. Liu, Ceram. Int., 35, 2455 (2009).

4. P. Ried, E. Bucher, W. Preis, W. Sitte, and P. Holtappels, ECS Transactions, 7, 1217, (2007).

5. E. Bucher, A. Egger, P. Ried, W. Sitte, and P. Holtappels, Solid State Ionics, 179, 1032 (2008)

6. E. Girdauskaite, H. Ullmann, V. V. Vashook, U. Guth, G. B. Caraman, E. Bucher, and W. Sitte, Solid State Ionics, 179, 385 (2008).

7. C. Niedrig, S. F. Wagner, W. Menesklou, S. Baumann, and E. Ivers-Tiffée, Solid State Ionics, 283, 30 (2015).

8. H. J. M. Bouwmeester, M. W. Den Otter, and B. A. Boukamp, J. Solid State Electrochem., 8, 599 (2004)

9. K. Asano, C. Niedrig, W. Menesklou, S. F. Wagner, and E. Ivers-Tiffée, J. Electrochem. Soc., 163, F302 (2016).

10. M. Burriel, C. Niedrig, W. Menesklou, S. F. Wagner, J. Santiso, and E. Ivers-Tiffée, Solid State Ionics, 181, 602 (2010).

11. L. Wang, R. Merkle, J. Maier, T. Acartürk, and U. Starke, Appl. Phys. Lett., 94, 071908 (2009).

12. H. J. M. Bouwmeester, C. Song, J. Zhu, J. Yi, M. van Sint Annaland, and B. A. Boukamp, Phys. Chem. Chem. Phys., 11, 9640 (2009).

13. J. Druce, H. Téllez, M. Burriel, M. D. Sharp, L. J. Fawcett, S. N. Cook, D. S. McPhail, T. Ishihara,H. H. Brongersma, and J. A. Kilner, Energy Environ. Sci., 7, 3593 (2014).

14. S. B. Adler, J. A. Lane, and B. C. H. Steele, J. Electrochem. Soc., 143, 3554 (1996).

15. S. B. Adler, Solid State Ionics, 111, 125 (1998).

16. A. Leonide, B. Rüger, A. Weber, W. A. Meulenberg, and E. Ivers-TiffeF́e, J. Electrochem. Soc., 157, B234 (2010).

17. C. Endler-Schuck, J. Joos, C. Niedrig, A. Weber, and E. Ivers-Tiffée, Solid State Ionics, 269, 67 (2015)

18. F. S. Baumann, J. Fleig, H. U. Habermeier, and J. Maier, Solid State Ionics, 177, 1071 (2006).

19. J. Hayd, H. Yokokawa, and E. Ivers-Tiffee, J. Electrochem. Soc., 160, F351 (2013).

20. F. Han, R. Mücke, T. V. Gestel, A. Leonide, N. H. Menzler, H. P. Buchkremer, and D. Stöver, J. Power Sources, 218, 157 (2012)

21. J. Hayd, U. Guntow, and E. Ivers-Tiffée, ECS Trans. 35, 2261 (2011).

22. J. Hayd, L. Dieterle, U. Guntow, D. Gerthsen, and E. Ivers-Tiffée, J. Power Sources, 196, 7263 (2011).

23. J. Hayd and E. Ivers-Tiffee, J. Electrochem. Soc., 160, F1197 (2013).

24. J. Weese, Comput.Phys. Commun., 69, 99 (1992).

25. J. Joos, M. Ender, T. Carraro, A. Weber, and E. Ivers-Tiffée, Electrochim. Acta, 82, 268 (2012).

26. J. Joos, T. Carraro, A. Weber, and E. Ivers-Tiffée, J. Power Sources, 196, 7302 (2011).

27. J. Joos, T. Carraro, M. Moses, B. Rüger, A. Weber, and E. Ivers-TiffeF́, ECS Trans., 35, 2357 (2011).

28. J. Joos, Ph.D. thesis, Microstructural Characterization, Modelling and Simulation of Solid Oxide Fuel Cell Cathodes, KIT Scientific Publishing, Karlsruhe, Germany (2016).

29. S. Mcintosh, J. F. Vente, W. G. Haije, D. H. A. Blank, and H. J. M. Bouwmeester, Chem. Mater., 18, 2187 (2006).

30. Y. M. Kim, P. K. Lohsoontorn, S. W. Baek, and J. Bae, Int. J. Hydrogen Energy, 36, 3138 (2011). 
31. S. Baumann, F. Schulze-Küppers, S. Roitsch, M. Betz, M. Zwick, E. M. Pfaff, W. A. Meulenberg, J. Mayer, and D. Stöver, J. Memb. Sci., 359, 102 (2010).

32. M. W. den Otter, Ph.D. thesis, A Study of Oxygen Transport in Mixed Conducting Oxides using Isotopic Exchange and Conductivity Relaxation, University of Twente, The Netherlands (2000)

33. B. Rüger, Ph.D. thesis, Mikrostrukturmodellierung von Elektroden für die Festelektrolytbrennstoffzelle, KIT Scientific Publishing, Karlsruhe, Germany (2009).

34. A. Häffelin, J. Joos, M. Ender, A. Weber, and E. Ivers-Tiffée, J. Electrochem. Soc., 160, F867 (2013).

35. Y. Takeda, R. Kanno, M. Noda, Y. Tomida, and O. Yamamoto, J. Electrochem. Soc. 134, 2656 (1987).

36. A. J. Darbandi and H. Hahn, Solid State Ionics, 180, 1379 (2009).

37. A. Leonide, B. Rüger, A. Weber, W. A. Meulenberg, and E. Ivers-TiffeF́e, J. Electrochem. Soc., 157, B234 (2010).

38. T. Kawada, J. Suzuki, M. Sase, A. Kaimai, K. Yashiro, Y. Nigara, J. Mizusaki, K. Kawamura, and H. Yugami, J. Electrochem. Soc., 149, E252 (2002).
39. Y. L. Yang, C. L. Chen, S. Y. Chen, C. W. Chu, and A. J. Jacobson, J. Electrochem Soc., 147, 4001 (2000)

40. C. Niedrig, S. Taufall, M. Burriel, W. Menesklou, S. F. Wagner, S. Baumann, and E. Ivers-Tiffée, Solid State Ionics, 197, 25 (2011)

41. J. Hayd, Ph.D. thesis, Nanoskalige Kathoden für den Einsatz in FestelektrolytBrennstoffzellen bei abgesenkten Betriebstemperaturen, KIT Scientific Publishing, Karlsruhe, Germany (2012).

42. L. Unger et al., (2017) submitted.

43. J. Druce, T. Ishihara, and J. Kilner, Solid State Ionics, 262, 893 (2014),

44. J. Szasz, F. Wankmüller, V. Wilde, H. Störmer, D. Gerthsen, N. H. Menzler, and E. Ivers-Tiffée, ECS Trans., 68, 763 (2015).

45. E. Bucher, M. Yang, and W. Sitte, J. Electrochem. Soc., 159, B592 (2012).

46. F. Wang, K. Yamaji, D.-H. Cho, T. Shimonosono, M. Nishi, H. Kishimoto, M. E. Brito, T. Horita, and H. Yokokawa, Fuel Cells, 13, 520 (2013).

47. S. Y. Lai, D. Ding, M. Liu, M. Liu, and F. M. Alamgir, ChemSusChem, 7, 3078 (2014). 